\title{
Chromosome analysis from peripheral blood lymphocytes of workers after an acute exposure to benzene
}

\author{
M GILLIAN CLARE,' A YARDLEY-JONES, ${ }^{2}$ A C MACLEAN, ${ }^{2}$ AND B J DEAN ${ }^{\prime}$ \\ From the Shell Toxicology Laboratory (Tunstall),' Sittingbourne Research Centre, Sittingbourne, Kent ME9 \\ $8 A G$, and Shell UK Oil, ${ }^{2}$ PO Box No 3, Stanlow, Ellesmere Port, South Wirral L65 4HB, UK
}

ABSTRACT A spillage of about 1200 gallons of benzene occurred during the loading of a ship, and 10 workers on a single shift were exposed to benzene. Shortly afterwards, an assay of the urine of these individuals showed that substantial amounts of phenol were being excreted. About three months after the incident samples of venous blood were taken from 10 individuals exposed to benzene and 11 men on a comparable shift who acted as controls. The lymphocytes were stimulated to divide in short term cultures. For each subject, 200 cells at metaphase were examined for chromosome damage using $48 \mathrm{~h}$ cultures, and sister chromatid exchanges (SCE) were analysed from about 30 cells in their second division, using $72 \mathrm{~h}$ cultures. The most frequent types of aberrations in all the individuals were chromatid gaps, with occasional breaks of chromatids and chromosomes. There were few exchanges within or between the arms of chromatids or chromosomes. More cells in the control than in the exposed group showed damage, an effect that was especially noticeable for chromatid gaps. All values, however, were considered to be within a normal range. There were slightly more SCE in some of the exposed individuals than in the controls and there was a trend towards a positive association between the frequency of SCE recorded for each individual and the maximum value for the excretion of phenol in the urine on the day after the incident. There is no evidence to indicate that benzene induced any type of lasting chromosome damage in the lymphocytes of the 10 exposed workers when cells were examined about three months after the incident.

People exposed to benzene may be at an increased risk of developing leukaemia, pancytopaenia, and chromosomal aberrations compared with people not so exposed. ${ }^{1}$ Men employed in factories where benzene had been used as a solvent had significantly more chromosome aberrations in their peripheral blood lymphocytes than those working in areas where toluene had been substituted for benzene. ${ }^{23}$ In these studies exposure to benzene took place over a long period, and it is impossible accurately to estimate details of exposure in retrospect, but exposure must be assumed to have been high.

At Stanlow, Cheshire, on 8 January 1981 some 1200 gallons of benzene were accidentally released into the dock and on to the surrounding berth. The

Received 22 December 1982

Accepted 15 March 1983 amount of phenol in the urine of some of the men had been estimated the day before, or on the day of the spillage. Shortly after the incident, assays of the urine of 10 workers on a single shift who were present on the dockside showed that substantial amounts of phenol were being excreted. These results confirmed that most of these men had been exposed briefly to a high concentration of benzene. ${ }^{4}$

About three months after the incident, samples of peripheral blood were collected from these men and from 11 individuals from another shift at Stanlow and forwarded to the Shell Toxicology Laboratory. The lymphocytes were stimulated to divide in tissue culture medium. Cells were examined for all types of chromosome damage and for sister chromatid exchanges (SCE). The results for the workers on the two shifts were compared, since the two groups were similar apart from their exposure to the benzene spillage. 


\section{Procedures}

Samples of $10 \mathrm{ml}$ blood were obtained by venepuncture from all subjects on four separate days between 28 April and 6 May 1981. The samples were transported by road in polystyrene collection tubes containing 500 IU dried heparin. Short term cultures were initiated on receipt of the samples. A number from one to 21 was randomly allocated to each sample.

The detailed method for the culture, harvesting, and staining of lymphocytes has been described ${ }^{5}$ and will only be outlined here. The method for staining chromosomes to show SCE was modified from that described by Perry and Wolff. ${ }^{6}$

Tubes containing the whole blood were gently shaken to mix the plasma and cells, and $0.8 \mathrm{ml}$ was removed aseptically and added to a sterile $30 \mathrm{ml}$ universal tube containing $10 \mathrm{ml}$ of Hams F10 culture medium (supplied in powder form by Flow Labs Ltd and sterilised by filtration), supplemented with fetal calf serum, sodium bicarbonate solution, benzyl penicillin, streptomycin sulphate and phytohaemagglutinin. To half the containers, 5-bromode-oxyuridine was added, to a final concentration of $3.07 \mu \mathrm{g} / \mathrm{ml}$ (10 $\mu$ moles). For each sample, four cultures were incubated at $37^{\circ} \mathrm{C}$, two for $48 \mathrm{~h}$ for chromosome analysis and two containing 5-bromode-oxyuridine for $72 \mathrm{~h}$ for counting SCE. These latter cultures were incubated in complete darkness and subsequent processing was performed under subdued lighting conditions until the potassium chloride solution was added. Three hours before the end of the incubation period, Colcemid solution was added to a final concentration of 0.2 $\mu \mathrm{g} / \mathrm{ml}$.

Tubes of medium containing the cells were centrifuged at $1000 \mathrm{rpm}$ for eight minutes and the supernatant was discarded. The pellets of cells were resuspended in $10 \mathrm{ml}$ of $0.075 \mathrm{M}$ potassium chloride solution and incubated at $37^{\circ} \mathrm{C}$ for eight minutes. The centrifugation process was repeated and the supernatant was discarded. A fixative solution containing three parts of methanol to one part of glacial acetic acid was added to each pellet of cells. Centrifugation was repeated twice more, each time resuspending the cells in fresh fixative. For each culture, two slides were prepared.

Those slides prepared from cultures terminated at $72 \mathrm{~h}$ were stained for 12 minutes in a solution containing $5 . \mu \mathrm{g} / \mathrm{ml}$ Hoechst 33258 , diluted in distilled water. After rinsing, they were transferred to a solution containing $8.4 \mathrm{~g}$ trisodium citrate and $17.4 \mathrm{~g}$ sodium chloride per litre. The differential fluorescence between the sister chromatids was developed by exposing the cells to ultraviolet light at a wavelength of about $360 \mathrm{~nm}$. The slides were then warmed in the salt solution to $80^{\circ} \mathrm{C}$ and incubated at this temperature for $\mathbf{1 0}$ minutes before being rinsed thoroughly in distilled water. All slides were stained with a solution of Giemsa.

Generally, 200 cells at metaphase were analysed for chromosome damage from each subject, using cultures incubated for $48 \mathrm{~h}$. Numbers of chromosomes were counted in at least five cells from each individual. Using the slides prepared from cultures terminated at $72 \mathrm{~h}$, cells at metaphase in their second division which had clearly differentially stained chromosomes were chosen to count SCE. For most samples more than 1000 chromosomes within 30 cells were scored. SCE about the centromere were counted only when clearly distinguishable from chromosome twisting. The frequency of SCE for the whole sample was expressed:

Frequency of SCE per chromosome =

Total number of SCE

Total number of chromosomes.

When the analysis was completed, the samples were decodified. Values for the excretion of phenol in the urine of the employees present at the spillage of benzene were provided by the medical department at Stanlow.

\section{Results}

\section{CHROMOSOME ABERRATIONS}

All cells that were counted contained 46 chromosomes. The numbers of cells showing aberrations were recorded for each individual and the percentages of cells showing damage were calculated (table 1).

When the results for the two shifts were collated, there were more cells showing all of the categories of damage in the control than in the exposed group (table 2). Significantly more gaps were registered in the control than in the exposed group $(p<0 \cdot 05)$.

\section{SCE AND PHENOL EXCRETION}

Owing to bacterial contamination, not all of the samples could be examined for SCE (table 3 ). There was considerable variation in the frequencies of SCE in different individuals, particularly those exposed to benzene. The average frequency of SCE per chromosome was slightly higher in the exposed compared with the control group, but the difference was not statistically significant $(p>0.05)$.

The values for phenol in the urine of the individuals exposed to benzene varied, even when sampled at different times on the same day, though this may be partly due to changes in the degree of 
Table 1 Percentage of cells showing chromosome damage in peripheral blood of workers exposed (individuals 1-10) or not exposed (11-21) to spillage of benzene

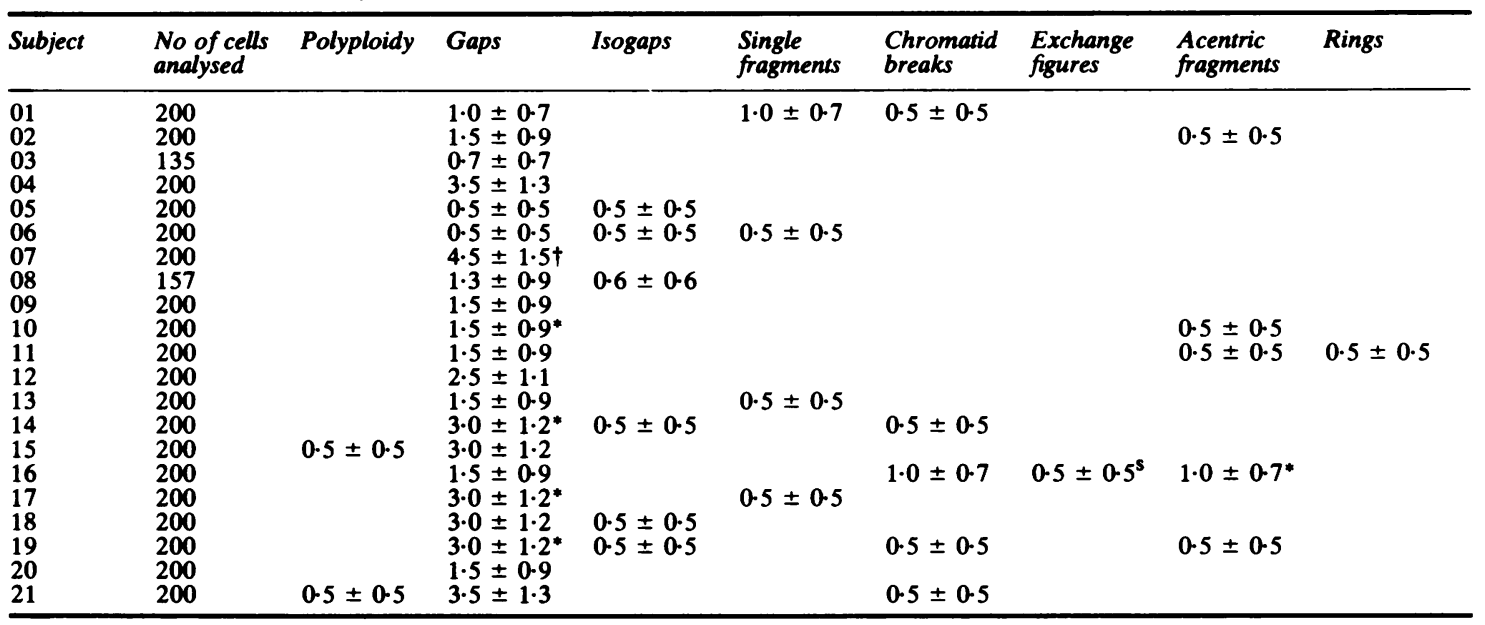

* One cell contained two aberrations.

fOne cell contained three aberrations.

3Exchange figure was a single ring.

All results \pm 1 SE. Standard error was calculated on basis of a Poisson distribution of aberrations within cells. Men with CYT numbers 1-10 were exposed to the benzene spillage and those with numbers 11-21 were not.

The average age of individuals 1-10 was 47, while that of individuals 11-21 was 44 when blood was collected.

Table 2 Percentage of cells showing damage in the two shifts

\begin{tabular}{|c|c|c|c|c|c|c|c|}
\hline \multirow{2}{*}{ Group } & \multirow{2}{*}{$\begin{array}{l}\text { No of } \\
\text { cells }\end{array}$} & \multicolumn{2}{|c|}{ Percentage of cells showing } & \multirow[b]{2}{*}{$\begin{array}{l}\text { Chromatid } \\
\text { breaks }\end{array}$} & \multirow[b]{2}{*}{$\begin{array}{l}\text { Chromatid } \\
\text { exchanges }\end{array}$} & \multirow[b]{2}{*}{$\begin{array}{l}\text { Acentric } \\
\text { fragments }\end{array}$} & \multirow[b]{2}{*}{$\begin{array}{l}\text { Chromosome } \\
\text { exchanges }\end{array}$} \\
\hline & & Polyploidy & $\begin{array}{l}\text { Gaps and } \\
\text { isogaps }\end{array}$ & & & & \\
\hline $\begin{array}{l}\text { Exposed } \\
\text { Controls }\end{array}$ & $\begin{array}{l}1892 \\
2200\end{array}$ & $\begin{array}{l}0 \\
0.09 \pm 0.06\end{array}$ & $\begin{array}{l}1.69 \pm 0.30 \\
2.55 \pm 0.34\end{array}$ & $\begin{array}{l}0.21 \pm 0.11 \\
0.32 \pm 0.12\end{array}$ & $\begin{array}{l}0 \\
0.05 \pm 0.05\end{array}$ & $\begin{array}{l}0.11 \pm 0.07 \\
0.18 \pm 0.09\end{array}$ & $\begin{array}{l}0 \\
0.05 \pm 0.05\end{array}$ \\
\hline
\end{tabular}

All results \pm 1 SE.

*Chromatid breaks include single fragments.

Table 3 Frequency of SCE in cultures from different individuals exposed (1-10) or not exposed (12-20) to spillage of benzene

\begin{tabular}{|c|c|c|c|c|c|}
\hline Subject & No of cells & No of SCE & No of chromosomes & $\begin{array}{l}\text { SCE per chromosome } \\
\pm I S E\end{array}$ & No of cells with $>10$ SCE \\
\hline $\begin{array}{r}1 \\
2 \\
3 \\
4 \\
5 \\
6 \\
7 \\
8 \\
9 \\
10\end{array}$ & $\begin{array}{l}30 \\
30 \\
28 \\
30 \\
30 \\
30 \\
30 \\
20 \\
30 \\
30\end{array}$ & $\begin{array}{l}116 \\
171 \\
196 \\
179 \\
161 \\
167 \\
186 \\
108 \\
210 \\
180\end{array}$ & $\begin{array}{r}1226 \\
1235 \\
1148 \\
1220 \\
1189 \\
1257 \\
1349 \\
698 \\
1265 \\
1330\end{array}$ & $\begin{array}{l}0.09 \pm 0.01 \\
0.14 \pm 0.01 \\
0.17 \pm 0.01 \\
0.15 \pm 0.01 \\
0.14 \pm 0.01 \\
0.13 \pm 0.01 \\
0.14 \pm 0.01 \\
0.15 \pm 0.01 \\
0.17 \pm 0.01 \\
0.14 \pm 0.01\end{array}$ & $\begin{array}{l}0 \\
3 \\
6 \\
2 \\
1 \\
1 \\
3 \\
1 \\
6 \\
5\end{array}$ \\
\hline $\begin{array}{l}12 \\
17 \\
18 \\
19 \\
20\end{array}$ & $\begin{array}{l}30 \\
30 \\
30 \\
15 \\
30\end{array}$ & $\begin{array}{r}102 \\
167 \\
131 \\
75 \\
138\end{array}$ & $\begin{array}{r}854 \\
1285 \\
1191 \\
634 \\
1237\end{array}$ & $\begin{array}{l}0.12 \pm 0.01 \\
0-13 \pm 0.01 \\
0-11 \pm 0.01 \\
0-12 \pm 0.01 \\
0.11 \pm 0.01\end{array}$ & $\begin{array}{l}1 \\
3 \\
1 \\
1 \\
1\end{array}$ \\
\hline
\end{tabular}

Ten exposed individuals were measured. Average frequency of SCE per chromosome ( \pm 1 SD) was $0 \cdot 14 \pm 0 \cdot 02$. Five control individuals were measured. Their average frequency of SCE per chromosome ( \pm 1 SD) was $0.12 \pm 0.01$. 
Table 4 Values for phenol in urine ( $\mathrm{mg} / \mathrm{l})$ of workers exposed to benzene

\begin{tabular}{|c|c|c|c|c|c|}
\hline Subject & 2 Jan 1981 & 7 Jan 1981 & 8 Jan 1981 & 9 Jan 1981 & $12 \operatorname{Jan} 1981$ \\
\hline $\begin{array}{r}1 \\
2 \\
3 \\
4 \\
5 \\
6 \\
7 \\
8 \\
9 \\
10\end{array}$ & 21 & $\begin{array}{l}5 \\
4 \\
2 \\
9\end{array}$ & $\begin{array}{l}34,118,127 \\
20 \\
213 \\
331 \\
18,184,12 \\
16 \\
154, \\
226,112,144,172,175 \\
12,256 \\
84,97,74,44\end{array}$ & 48,36 & $\begin{array}{r}8 \\
16 \\
12 \\
17 \\
6 \\
5\end{array}$ \\
\hline
\end{tabular}

exposure during that period (table 4).

Workers in the exposed group, for whom high maximum concentrations of urinary phenol were recorded, tended to show higher frequencies of SCE in their lymphocytes than those with low maximum phenol values (fig).

There is a positive correlation between those values $(r=0.55)$, though this is not statistically significant $(0.05<\mathrm{p}<0 \cdot 10)$.

\section{Discussion}

When harvested for the analysis of chromosome aberrations at $48 \mathrm{~h}$, the majority of cells will be in their first division. ${ }^{5}$ Since asymmetrical exchanges are more readily detectable than symmetrical exchanges on conventionally stained preparations, translocations and inversions are noticed infre- quently, ${ }^{7}$ so their absence in this study was not surprising.

Since storage of blood after treatment does not affect the frequency of chromosome aberrations subsequently recorded, ${ }^{8}$ the delay in the initiation of cultures after the blood had been taken was not considered to influence subsequent analysis.

The men who were employed on the two shifts were considered to form two similar groups, differing only in respect of their exposure to the benzene spillage. Thus the control shift forms a useful basis with which to compare the results from workers exposed to this spillage.

The values for the frequencies of aberrations obtained from both groups of workers are in agreement with those reported by other authors for subjects not known to have been recently exposed to any chromosome breaking agents. ${ }^{9-12}$

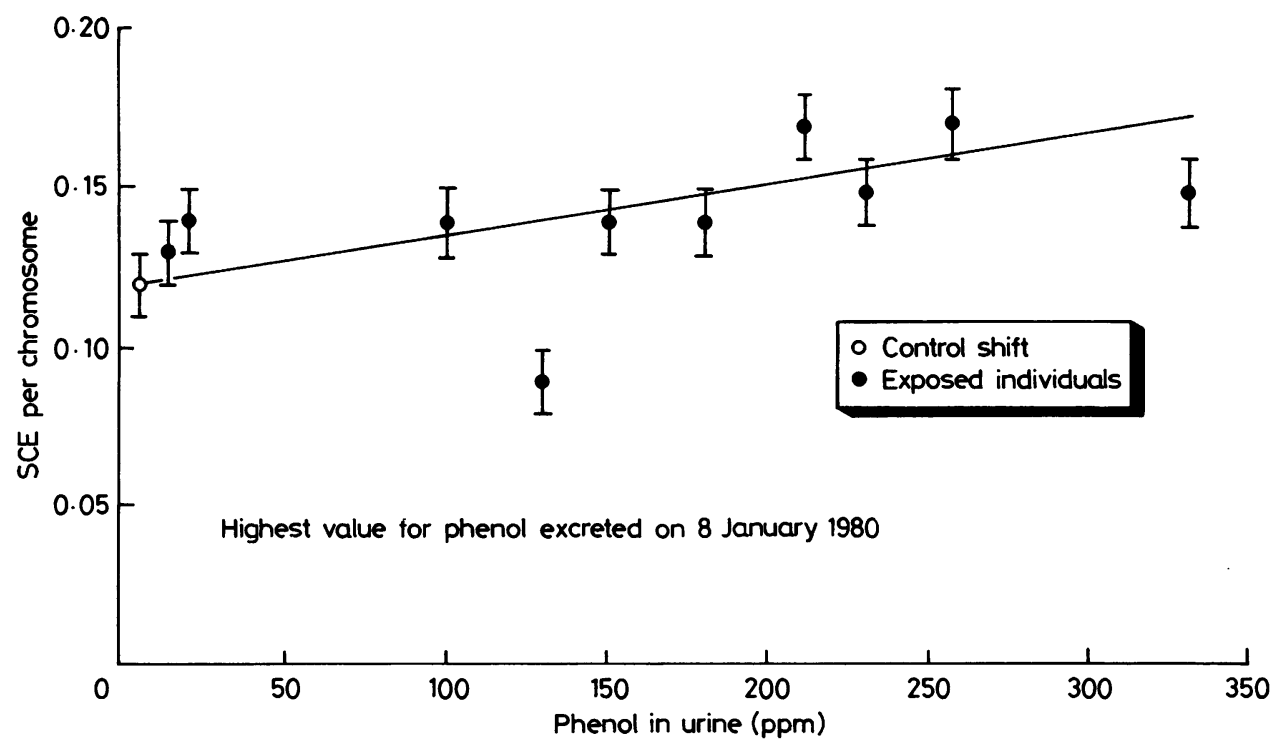

Relation between phenol excretion and frequency of sister chromatid exchanges (SCE). 
Similar amounts of chromosome damage were recorded in the control and exposed groups. This suggests either that exposure to the benzene spillage did not induce chromosome damage, or that any damage induced was eliminated in the interval between the incident and the chromosome analysis. ${ }^{13}$ Nevertheless, human exposure to benzene has been associated with slight, but significantly increased, amounts of chromosome damage, ${ }^{231415}$ even when cells were analysed several years after the concentration of benzene had been reduced in the workplace. Potentially, the men in such studies had been exposed to high ambient concentrations of benzene for up to about 20 years. Thus the amount of benzene was probably much greater than that received by the subjects in the present study and the exposure was chronic rather than acute.

Benzene, at $3100 \mathrm{ppm}$ for $4 \mathrm{~h}$, induced SCE but not chromosome damage in the bone marrow cells of mice. ${ }^{16}$ Where the peripheral blood lymphocytes of workers exposed to benzene have been examined for SCE, equivocal results have been reported. ${ }^{17} 18$ Compared with conventional chromosome damage, SCE are considered to be a transient phenomenon. ${ }^{19}$ Therefore we consider it to be unlikely that the weak association between the maximum concentrations of urinary phenols and the frequencies of SCE in blood samples collected three months after the spillage of benzene was related to this particular incident.

\section{Conclusions}

The results provide no evidence for the presence of long term lesions to the DNA, as manifested by chromosome damage, in the lymphocytes of the 10 workers exposed to the spillage of benzene.

We are grateful for the skilled technical help provided by Mrs $\mathrm{L} \mathrm{J}$ Reynolds, and to $\mathrm{Mr} \mathrm{H}$ Bloomberg, Medical Centre, Stanlow, who collected the blood samples and performed the biochemical analysis.

Financial support was provided by Shell UK Oil.

\section{References}

' Environmental Protection Agency. Assessment of health effects of benzene germane to low-level exposure. Washington: EPA, 1978:1-111. (EPA-600/1-78-061.)
2 Tough IM, Court Brown WM. Chromosome aberrations and exposure to ambient benzene. Lancet 1965; i: 684 .

${ }^{3}$ Forni A, Pacifico E, Limonta A. Chromosome studies in workers exposed to benzene or toluene or both. Arch Environ Health 1971;22:373-8.

- Truhaut R, Murray R. International workshop on toxicology of benzene, Paris 9-11 November 1976. Int Arch Occup Environ Health 1978;41:65-76.

s Evans HJ, O' Riordan ML. Human peripheral blood lymphocytes for the analysis of chromosome aberrations in mutagen tests. In: Kilbey BJ, Legator MS, Nichols W, Ramel C, eds. Handbook of mutagenicity test procedures. Oxford: Elsevier, 1977;261-74.

- Perry P, Wolff S. New Giemsa method for the differential staining of sister chromatids. Nature 1974;251:156-8.

' Evans HJ. Chromosome aberrations induced by ionizing radiations. Int Rev Cytol 1962;13:221-321.

- Vekemans M, Leonard A. Influence of blood storage after in vitro exposure to ionizing radiations on the yield of chromosome aberrations observed in human lymphocytes. Int J Radiat Biol 1977;31:493-8.

- O' Riordan ML, Evans HJ. Absence of significant chromosome damage in males occupationally exposed to lead. Nature 1974;247:50-3.

${ }^{10}$ McKenzie WH, Knelson JH, Rummo NJ, House DE. Cytogenetic effects of inhaled ozone in man. Mutat Res 1977;48:95102.

" Kucerova M, Zhurkov VS, Polivkova Z, Ivanova JE. Mutagenic effect of epichlorohydrin. II. Analysis of chromosomal aberrations in lymphocytes of persons occupationally exposed to epichlorohydrin. Mutat Res 1977;48:355-60.

12 Purchase IFH, Richardson CR, Anderson D, Paddle GM, Adams WGF. Chromosomal analyses in vinyl chlorideexposed workers. Mutat Res 1978;57:325-34.

13 Preston RJ, Au W, Bender MA, et al. Mammalian in vivo and in vitro cytogenetic assays: a report of the US EPA's Gene-Tox Program. Mutat Res 1981;87:143-88.

${ }_{14}$ Tough IM, Smith PG, Court Brown WM, Harnden DG. Chromosome studies on workers exposed to atmospheric benzene. The possible influence of age. Eur $J$ Cancer 1970;6:4955.

is Dean BJ, Genetic toxicology of benzene, toluene, xylenes and phenols. Mutat Res 1978;47:75-97.

${ }^{16}$ Tice RR, Costa DL, Drew RT. Cytogenetic effects of inhaled benzene in murine bone marrow: induction of sister chromatid exchanges, chromosomal aberrations and cellular proliferation inhibition in DBA/2 mice. Proc Natl Acad Sci USA 1980;77:2148-52.

17 Funes-Cravioto F, Zapata-Gayon C, Kolmodin-Hedman B, et al. Chromosome aberrations and sister-chromatid exchange in workers in chemical laboratories and a rotoprinting factory and in children of women laboratory workers. Lancet 1977;ii:322-5.

${ }^{18}$ Watanabe T, Endo A, Kato Y, Shima S, Watanabe T, Ikeda M. Cytogenetics and cytokinetics of cultured lymphocytes from benzene-exposed workers. Int Arch Occup Environ Health 1980;46:31-41.

${ }^{19}$ Stetka DG, Wolff S. Sister chromatid exchange as an assay for genetic damage induced by mutagen-carcinogens. 1 . In vivo test for compounds requiring metabolic activation. Mutat Res 1976;41:333-42. 